\title{
The Teaching of Listening Strategies in ESL Classrooms
}

\section{Noor Syazana Che Ismail, Azlina Abdul Aziz}

\author{
To Link this Article: http://dx.doi.org/10.6007/IJARBSS/v10-i6/7279
}

DOI:10.6007/IJARBSS/v10-i6/7279

Received: 09 April 2020, Revised: 02 May 2020, Accepted: 29 May 2020

Published Online: 10 June 2020

In-Text Citation: (Ismail \& Aziz, 2020)

To Cite this Article: Ismail, N. S. C., \& Aziz, A. A. (2020). The Teaching of Listening Strategies in ESL Classrooms. International Journal of Academic Research in Business and Social Sciences, 10(6), 197-209.

\section{Copyright: (c) 2020 The Author(s)}

Published by Human Resource Management Academic Research Society (www.hrmars.com)

This article is published under the Creative Commons Attribution (CC BY 4.0) license. Anyone may reproduce, distribute, translate and create derivative works of this article (for both commercial and non-commercial purposes), subject to full attribution to the original publication and authors. The full terms of this license may be seen

at: http://creativecommons.org/licences/by/4.0/legalcode

Vol. 10, No. 6, 2020, Pg. $197-209$

Full Terms \& Conditions of access and use can be found at http://hrmars.com/index.php/pages/detail/Publication-ethics 


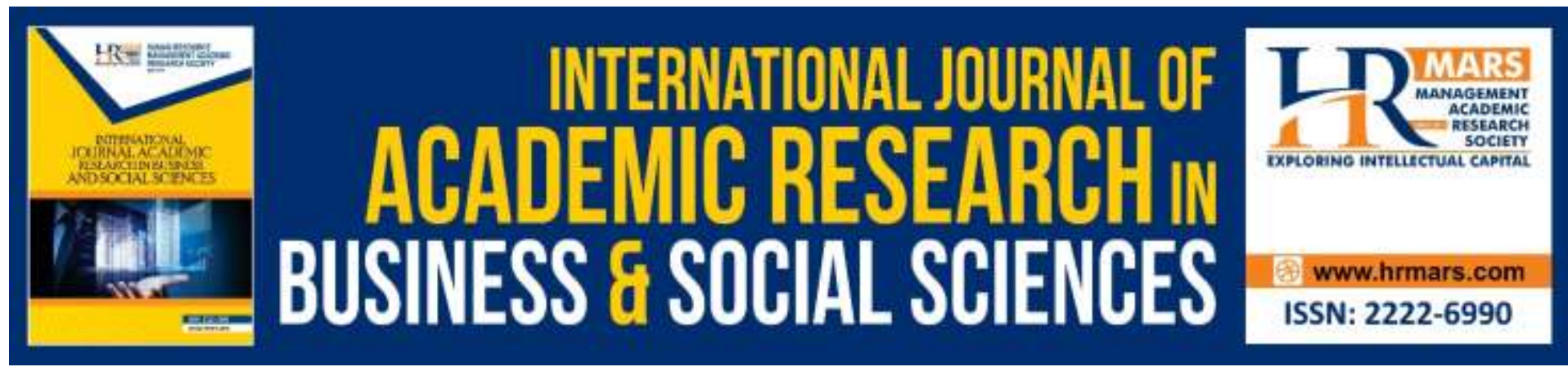

\title{
The Teaching of Listening Strategies in ESL Classrooms
}

\author{
Noor Syazana Che Ismail, Azlina Abdul Aziz \\ Faculty of Education, Universiti Kebangsaan Malaysia, Selangor, Malaysia \\ Email: noorsyazana2013@gmail.com, azlina1@ukm.edu.my
}

\begin{abstract}
Listening skill is often overlooked by its sister skill, speaking. To develop a deeper understanding of the teaching of listening strategies in ESL classrooms, this paper presents a systematic review of past-related studies of the same focus area from the year 2004 to 2016. This paper aims to address two research questions; i) what listening models/strategies are utilised in ESL classroom and ii) what interventions are used to inculcate listening strategies taught in ESL classrooms. Results indicate that three listening strategies are often exploited; bottom-up processing, top-down processing and interactive processing. The findings of pastrelated studies illuminate that interactive processing is better in serving the purpose of improving listening comprehension skill holistically.
\end{abstract}

Keywords: Listening Skills, Listening Strategies, Teaching Listening Strategies.

\section{Introduction}

To master the English language as a second language, both teachers and learners face numerous difficulties. This resulted in more research and development of new teaching strategies to improve English Language Learners (ELL's) language proficiency and competencies (De Brito, 2015). Arabi Zanjani and Izadpanah (2016) emphasise learners are expected to have necessary skills such as listening, reading, writing and speaking to be regarded as language learners. These four skills are intertwined and can hardly be used separately.

While all skills are crucial, a few studies accentuate writing and reading as the most important skills compared to others. Zakaria \& Abdul Aziz (2019) emphasizes writing as the most fundamental skill in developing English language as one's second language. Another study deems the key skill in mastering English as a second language is reading skill Ying \& Aziz, 2019). However, it is nearly impossible to omit listening in an English language lesson for its role in communication despite it being the least concerned skill (Yavuz \& Celik, 2017). When communicating, listening takes up $40-50 \%$ of the total time. Meanwhile, speaking, reading and writing take up $25-30 \%, 11-16 \%$ and $9 \%$ respectively (Yildirim \& Yildırim, 2016). Apart from that, the most important aspect when one begins to learn a language, he or she should first listen for them to understand the spoken language (Ahmadi, 2016).

Similar to reading, writing, and speaking, listening is an intricate process best developed by constant practice. It is an essential skill provides the foundation for effective 
communication and career success. It enhances the ability to learn and adapt new information, knowledge, and skills (Liubinienè, 2009). Listening skill consists of several main elements. They are distinguishing sounds, words recognition and understanding, identifying grammatical groupings, identifying significant phrases and utterances, associating linguistic, non-linguistic and paralinguistic cues, predicting and confirm meanings using background knowledge, recalling important details (Tyagi, 2013).

However, many researches exposed that both teachers and learners have neglected listening skill and they believed that listening skill can be developed naturally without much guidance (Abdalhamid, 2012). Although English is used globally in the education sector including primary schools, secondary schools, colleges, universities, seminars and conferences, it was not given sufficient attention in the research realm (Yukselci, 2003). In another research, listening and speaking skills that are categorised as receptive language skills are left out mainly because these skills are not parts of the examination (Sanjana, 2014). As a result, the education system produced good writers but they are not proficient in listening and speaking skills even after studying English for years. This should be a vital issue to be concerned about especially in the context of current curriculum used in Malaysian English education. It adapted Common European Framework of Reference for Languages, or widely known as CEFR that stresses on improving students' receptive and productive skills (Johar \& Abdul Aziz, 2019).

Therefore, good use of teaching listening strategies is needed to maximise the learning of listening. Hashim, Yunus, \& Hashim (2018) advocate that teaching students about learning strategies will help them to improve as better language learners. Regardless of teaching and developing students' listening skill importance, many teachers failed to emphasizes it enough. In a study involving three different types of school in Malaysia, Lim (2013) states all schools paid less attention in developing students' listening skill compared to reading, writing and speaking skill. Linang (2005) outlines a few reasons that causes this issue:

(i) Teachers assuming listening skill is to be developed naturally.

(ii) Teachers are not well equipped with strategies to teach listening skill.

(iii) Lack of emphasize on teaching listening skill in teacher education programs.

Thus, this study is conducted to systematically review past studies to help teachers learn more on listening strategies used and apply them in their lessons later on. Students can later develop their own most effective means of learning strategies (Basri et al., 2019).

Ivaarsson (2013) categorises listening strategies based O'Malley's and Chamot's language learning strategies (Liu, 2010) where the strategies include metacognitive strategy, cognitive strategy and social-affective strategy. Mejila et al. (2014) on the other hand classified listening strategies based on input processes of the learner. The first strategy is the top-down strategy (listener based) and the second strategy is the bottom-up strategy (textbased). Both language learners and teachers might prefer some strategies to others. This increases concerns on identifying the most efficient and less efficient listening strategies to be utilised in teaching listening skill (Mahmoud Ghoneim, 2013). These strategies need to be taught to enable the language learners to deal with incoming speech, particularly when comprehension is not complete (Yukselci, 2003). Thus, this study aims to find out the strategies used in teaching listening skills.

\section{Research Objectives}

This systematic review aims to present a synthesis of past studies on the teaching of listening strategies in ESL classrooms as well as to find out the intervention used in calculating such 
strategies.

\section{Research Questions}

The research questions for this study are:

(i) What are the listening models/strategies utilised in the ESL classroom?

(ii) What interventions are used to inculcate listening strategies taught in ESL classrooms?

\section{Literature Reviews \\ Listening Comprehension Skill}

Listening skill differs from other language skills in which listening is a receptive skill and the main goal in listening skill is to make sense of the speech and find the meanings rather than the language form itself (Sevik, 2012). It acts as the primary means of learning information and incoming ideas (Hamouda, 2013). Santos (2018) defines listening as the process of selecting and assigning meanings to sounds. In a listening process, learners select important information to listen. This is evidenced in our everyday lives where we indirectly attempt to give importance to things we recognised and what we want to hear.

Past studies showed that listening skill is more than often was neglected and undervalued. This includes past study in the context of learning English as a second language by Hamouda (2013) where he concludes the teaching of listening comprehension has been neglected and poorly taught. Listening skill is usually developed incidentally alongside speaking skill. However, it has now gained its rightful place in current language curriculum development where communicative skills are now emphasised (Vandergrift \& Goh, 2009) as developing the skill listening comprehension skills is a necessity in improving communication competence (Choo \& Md. Yunus, 2016).

Findings on past studies revealed contrary to many beliefs and assumptions; listening skill turns out to be the most important language skill in terms of the language learning process, the most widely used language skill and the fastest skill that can be developed to facilitate the development of other language skills (Hamouda, 2013). Listening awakens language comprehension as it is a receptive capacity that first evolves in a human being (Renukadevi, 2014). This means listening skill needs to be more feasible compared to other skills in the process of acquiring a second language. Because of the challenges of improving the listening skill, the teacher has to incorporate listening strategies that hold the student's attention high to promote the learning process. The content of the instruction should be interesting for the students and the students can identify all the listening components (Abbas Pourhosein Gilakjani \& Sabouri, 2016).

\section{Listening Skill Issues}

Before proceeding with strategies and intervention to improve listening comprehension skill, Chen (2005) and Renandya and Farrell (2011) outline several causes that hinder listening comprehension:

- Speech is fast: Speech rate is correlated with comprehension success. A faster speech rate may result in a decrease in listening comprehension.

- Variation of speech: Speakers may drop, modify, add sounds or undergo radical phonological changes when speaking. This makes it difficult for listeners to recognize some words.

- Blurry word boundaries: Words tend to blend with surrounding words making it 
incomprehensible for some listeners.

- A struggle in processing speech in real-time: Listeners have little control over what the speaker is saying and the speed at which the speaker conveys his or her message.

\section{Listening Skill Strategies}

Considerable research efforts have been made to understand listening strategies so the above problems faced by second language learners can be solved. Defining listening strategies is not an easy task either as different scholars defined it differently from varying point of views. According to Bao (2017), learning strategy is techniques, approaches, methods and thoughtful actions employed to ease learning. It is also defined as conscious behaviours of language learners to facilitate the acquisition, storage, retention and use of information.

\section{Bottom-up Processing}

O'Malley et al. (1989) categorise listeners who interpret meaning based on linguistic characteristics of the texts as those who use bottom-up processing. They make use of their schemata in long-term memory that consists of grammatical or syntactic rules. Listeners begin interpreting the meaning of the audio texts by first determining the meaning of individual words and later aggregate upwards to larger units of meaning. Bottom-up processing trains listeners to incorporate word-for-word translation, adjusting to the speech rate, oral text repetition and focusing more on prosodic features of the text (Abdalhamid et al., 2012). Intentional listening is necessary for language learning and it employs strategies for identifying sounds and constructing meaning from the speeches (Mejila et al., 2014). In the context of learning English as a second language, this strategy may face interference from the first language as sounds, segmentations and linguistic markers of the two languages may differ and confuse the learners.

\section{Top-down processing}

On the contrary, listeners who often make effective use of schematic knowledge in analysing and giving meaning to the texts are applying top-down processing (O'Malley et al. 1989). They are drawing upon information in memory or upon analysis of text meaning for comprehension. Graham (2003) adds by utilising top-down processing, the learners use realworld schematic knowledge to develop expectations of the text meaning. It includes predicting, inferencing, elaborating and visualization. A study by Abdalhamid (2012) exposes the advanced listeners employed more top-down strategies compared to the intermediate listeners.

\section{Interactive Processing}

The interactive process happens when listeners employ both top-down and bottomup processing. Graham (2017) explains more successful listeners use a broader range of strategies with flexibility and they are more likely to use both top-down and bottom-up processing strategically. Thus, the general approach of the more effective learners was to use top-down processing and to rely upon bottom-up processing only as needed. Chamot (2004) adds ineffective listeners became embedded in determining the meanings of an individual word while effective listeners made use of both top-down and bottom-up processing strategies. 


\section{Methods}

This systematic review was conducted according to the suggested five steps of conducting a systematic review by Khan et al. (2003):

(i) Framing the question

(ii) Identifying relevant works

(iii) Assessing qualities of studies

(iv) Summarizing the evidence

(v) Interpreting the findings

The first step of carrying out this systematic review, which is framing the question is done to identify listening strategies used in ESL classrooms and interventions that incorporate those identified strategies. Later, relevant works or studies were identified. Past studies related to the research questions were searched using online databases such as Google Scholar, Mountain Scholar, Educational Resources Information Centre (ERIC), PubMed Central (PMC), SAGE Journal and Science Direct. The terminologies used to search for the past studies were listening comprehension skill, listening comprehension strategies and teaching of listening in ESL classrooms. The third step is done by reading the title, abstract and research questions of the articles chosen. The evidence and findings are tabulated and summarized.

\section{Results and Discussion}

After following the five steps of mentioned procedures in conducting a systematic review, three systematic reviews were done to answer the research questions. Six pastrelated studies published between 2004 and 2016 were reviewed. The findings are tabulated in Table 1, Table 2 and Table 3 as follows: 
Table 1: Summary of systematic reviews of past related studies on listening comprehension strategies

\begin{tabular}{|c|c|c|c|}
\hline Article/Study & $\begin{array}{c}\text { Number of } \\
\text { participants/studies }\end{array}$ & $\begin{array}{c}\text { Research } \\
\text { design }\end{array}$ & $\begin{array}{c}\text { Results } \\
\text { (Identified strategies of listening comprehension skills) }\end{array}$ \\
\hline $\begin{array}{l}\text { 1. A Study of Factors Affecting EFL } \\
\text { Learners' English Listening } \\
\text { Comprehension and the } \\
\text { Strategies for Improvement } \\
\text { (Abbas Pourhossein Gilakjani \& } \\
\text { Ahmadi, 2011) }\end{array}$ & 56 studies & $\begin{array}{c}\text { Comprehensive } \\
\text { review }\end{array}$ & $\begin{array}{l}\text { - Bottom-up processing: } \\
\circ \text { Listeners utilize their schemata hierarchically } \\
\text { from the most specific to general - decoding } \\
\text { phonemes, constructing words, phrases and } \\
\text { utterances to form a meaningful complete text. } \\
\text { Weakness: Mostly dependent on one's linguistic } \\
\text { knowledge. } \\
\text { - Top-down processing: } \\
\text { Employing higher-order schemata (prior } \\
\text { knowledge of context and situation) to } \\
\text { reconstruct the message and comprehend its } \\
\text { meaning. } \\
\text { Weakness: Unfamiliar context and situation } \\
\text { hinder the listeners' comprehension process. } \\
\text { Interactive processing: } \\
\text { Combination of both bottom-up and top-down } \\
\text { processing. }\end{array}$ \\
\hline
\end{tabular}


INTERNATIONAL JOURNAL OF ACADEMIC RESEARCH IN BUSINESS AND SOCIAL SCIENCES

Vol. 10, No. 6, June, 2020, E-ISSN: 2222-6990 @ 2020 HRMARS

2. Promoting Process-Oriented Listening Instruction in the ESL Classroom (Nguyen \& Abbot, 2016)

$\begin{array}{cc}6 \text { popular } & \text { Textbooks } \\ \text { intermediate adults } & \text { review }\end{array}$

ESL/EFL textbooks
- Bottom-up processing:

- Relies on the listeners' knowledge of segmentals and supra-segmentals to identify words and construct meaning

- Metacognitive approach:

- Engaging "learners in listening and thinking about their listening through an active iterative process, while they practice listening skills.

- Dual focused on listening-for-comprehension and listening-for-learning:

0 involves a two-part cycle of activities in listening lessons and materials: a comprehension phase and an acquisition phase-where the former focuses on extracting meaning, and the latter includes either form-focused noticing activities or restructuring activities.

Table 2: Summary of systematic reviews of past-related studies on developing listening skill issues

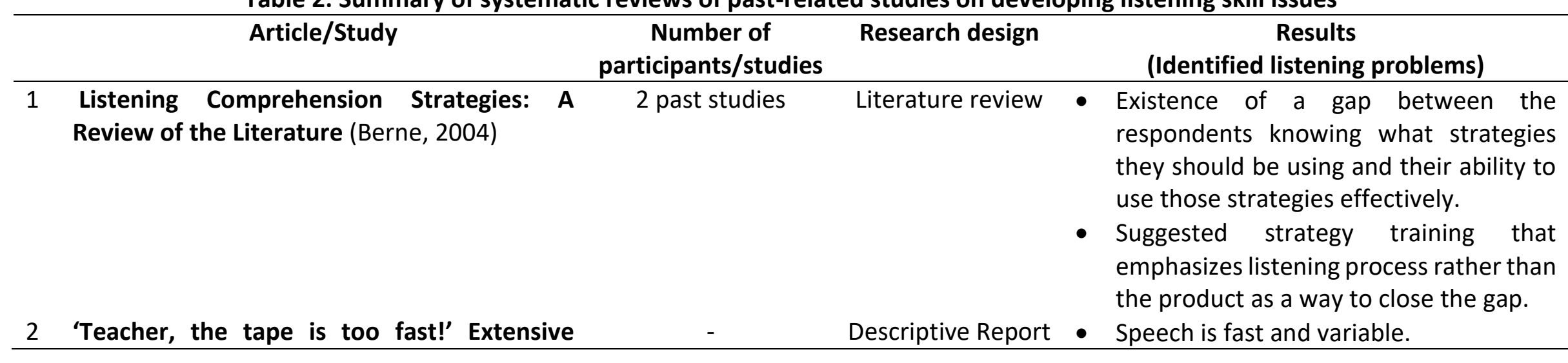


- Word boundaries are blurry.

- Inability to recognize words they knew.

- Missing subsequent input.

- Sentence complexity.

- Background knowledge.

- Unfamiliar pronunciation.

Table 3: Summary of systematic reviews on interventions used in developing listening skill

\begin{tabular}{|c|c|c|c|c|c|c|}
\hline & Article/Study & $\begin{array}{c}\text { Number of } \\
\text { participants/ } \\
\text { studies }\end{array}$ & $\begin{array}{l}\text { Research } \\
\text { design }\end{array}$ & $\begin{array}{c}\text { Type of } \\
\text { intervention }\end{array}$ & $\begin{array}{l}\text { Listening } \\
\text { strategies } \\
\text { targeted }\end{array}$ & Results \\
\hline 1. & $\begin{array}{l}\text { ESL Learners' Perception } \\
\text { And Attitudes } \\
\text { Towards The Use Of Podcast } \\
\text { In } \\
\text { Developing Listening Skills } \\
\text { (Hasan \& Tan, 2012) }\end{array}$ & $\begin{array}{l}53 \text { second-year } \\
\text { undergraduate } \\
\text { learners from Putra } \\
\text { University of } \\
\text { Malaysia }\end{array}$ & Pilot study & $\begin{array}{l}\text { Podcasts were } \\
\text { used as listening } \\
\text { materials. }\end{array}$ & $\begin{array}{l}\text { Interactive } \\
\text { processing } \\
\text { focusing on } \\
\text { product-based. }\end{array}$ & $\begin{array}{l}\text { - Learners are more willing } \\
\text { to participate in } \\
\text { developing listening skill } \\
\text { using podcasts at they can } \\
\text { control their learning. }\end{array}$ \\
\hline 2. & $\begin{array}{l}\text { Effect of Using Video } \\
\text { Materials in the Teaching of } \\
\text { Listening Skills for University } \\
\text { Learners (Woottipong, 2014) }\end{array}$ & $\begin{array}{l}41 \text { first-year English } \\
\text { major learners in } \\
\text { the second } \\
\text { semester of the } \\
\text { academic year } 2012 \\
\text { at Thaksin } \\
\text { University, Thailand }\end{array}$ & $\begin{array}{l}\text { Experimental } \\
\text { one group } \\
\text { pretest- } \\
\text { posttest } \\
\text { design }\end{array}$ & $\begin{array}{l}\text { The participants } \\
\text { were given } \\
\text { treatment by } \\
\text { using authentic } \\
\text { video materials in } \\
\text { improving } \\
\text { listening } \\
\text { comprehension. }\end{array}$ & $\begin{array}{l}\text { Interactive } \\
\text { processing: } \\
\text { Predicting, } \\
\text { making } \\
\text { connections, } \\
\text { visualizing, } \\
\text { inferring. }\end{array}$ & $\begin{array}{l}\text { - Teaching listening using } \\
\text { authentic video materials } \\
\text { improve participants' } \\
\text { learning comprehension } \\
\text { by enabling them to } \\
\text { connect the classroom and } \\
\text { the real world. } \\
\text { - Combination of visual } \\
\text { images and sound } \\
\text { stimulate interactive } \\
\text { processing of their } \\
\text { listening. }\end{array}$ \\
\hline
\end{tabular}


For the first section of this systematic review, two relevant studies were reviewed to get a more in-depth understanding of models and strategies of teaching listening skill and at the same time answer the first research question addressed in this study; what are the teaching listening skill models/strategies utilised by teachers in ESL classroom. Gilakjani and Ahmadi (2011) conducted a study titled 'A Study of Factors Affecting EFL Learners' English Listening Comprehension and the Strategies for Improvement' where they explore 56 past studies to conclude the strategies used in teaching listening comprehension. They outline bottom-up processing, top-down processing and interactive processing as the strategies in learning listening skill. Bottom-up processing is where listeners depend on their linguistic schemata from the most specific to general in order to put meanings into utterances. This inhibits some learners with less linguistic knowledge. Top-down processing, on the other hand, is where listeners employ higherorder schemata (prior knowledge of context and situation) to comprehend the messages. It requires more contextual and situational knowledge. Lastly, interactive processing that is the combination of both bottom-up and top-down processing is viewed as more effective strategy compared to its predecessor.

Apart from the bottom-up approach, Nguyen and Abbot (2016) added the metacognitive approach and dual focus on listening-for-comprehensions and listening-for-learning approach as strategies to teach the listening skill. The metacognitive approach aims to assist listeners in understanding the listening process and strategies which will later help them to develop selfregulated learners who can take control of their learning. Meanwhile, the dual focus approach involves two cycles or parts of listening activities: (i) comprehension phase where listeners aim to extract meaning and (ii) acquisition phase involves form-focused noticing activities or restructuring activities.

In other studies of models and strategies of teaching listening skill, researchers highlighted a few listening problems that can be addressed in future researches. Learners who are introduced to top-down and bottom-up strategies rated top-down strategies as more immediate while on the contrary they were able to utilise bottom-up strategies more easily. This gap which was identified by Berne (2004) should be a concern for future researchers when developing an intervention for the teaching of listening skill strategies. Renandya and Farrell (2011) highlight different types of learning listening skill problems such as; (i) fast speech rate, (ii) variation of speech in terms of pronunciation, context and accent, (iii) the stress of having to process speech in real-time, (iv) blurry word boundaries that confuse listeners when they are not in the context or situation, ( $v$ ) inability to recognize words they knew due to different pronunciation and accents, (vi) missing subsequent input, (vii) sentence complexity and (viii) limited background knowledge that hinder listeners from translating the meaning correctly.

On the other hand, several researchers focussed on utilising interventions to better introduce and incorporate strategies of teaching listening skill in their ESL classrooms. Woottipong (2014) for instance decided to use authentic video materials in the listening class to ease the interactive processing of listening such as predicting, making connections, visualizing, inferring. Hasan and Tan (2012) utilise podcast to integrate the listening strategies at the same time attracting learners' attention towards learning listening skill. More intervention can be developed to incorporate the teaching of listening skill strategies hence improve listening comprehension among ESL learners.

The findings of the study suggests that there are a number of teaching listening strategies 
teachers can utilise in their lessons. Concerning lack of exposure on teaching listening during teacher education programs, it is hoped that this systematic review can act as a guideline for teachers who wants to employs these strategies in their listening lessons. For future researchers, it is suggested to conduct a more in depth study on the same issue through qualitative research to gather more data from another angle as there is only a limited research was done on teaching listening skill in Malaysia, especially after the revamped curriculum was carried out.

\section{References}

Abdalhamid, F. (2012). LISTENING COMPREHENSION STRATEGIES OF ARABIC-SPEAKING ESL LEARNERS Submitted by. Colorado State University .

Abdalhamid, F., Ehlers-Zavala, F., \& Hirchi, M. (2012). THESIS LISTENING COMPREHENSION STRATEGIES OF ARABIC-SPEAKING ESL LEARNERS Submitted by.

Ahmadi, S. M. (2016). The Importance of Listening Comprehension in Language Learning. International Journal of Research in English Education, 1(1).

Ain Johar, N., \& Abdul Aziz, A. (2019). Teachers' Perceptions on Using the Pulse 2 textbook. Journal of Educational Research and Indigeneous Studies, 2(1).

Arabi Zanjani, B., \& Izadpanah, S. (2016). The Impact of Listening Strategies on Improving Learners' Listening Skill in Iran. Journal of Language Teaching and Research, 7, 1089. https://doi.org/10.17507/jltr.0706.04

Bao, X. (2017). A Study on Listening Strategies Instructed by Teachers and Strategies Used by Students. International Journal of English Linguistics, 7, 186.

https://doi.org/10.5539/ijel.v7n2p186

Basri, H., Hashim, H., \& Yunus, M. (2019). Using Google Apps as Learning Strategy to Enhance ESL Writing. Creative Education, 10, 2649-2657. https://doi.org/10.4236/ce.2019.1012192

Berne, J. E. (2004). Listening Comprehension Strategies: A Review of the Literature. Foreign Language Annals, 37(4), 521-531. https://doi.org/10.1111/j.1944-9720.2004.tb02419.x

Chamot, A. U. (2004). Issues in Language Learning Strategy Research and Teaching. Electronic Journal of Foreign Language Teaching, 1(1), 14-26.

Chen, Y. (2005). Barriers to Acquiring Listening Strategies for EFL Learners and Their Pedagogical Implications. The Electronic Journal for English as a Second Language, 8(5).

Choo, S. S., \& Md. Yunus, M. (2016). AUDIO CLIPS IN DEVELOPING LISTENING COMPREHENSION SKILLS IN MALAYSIAN PRIMARY ESL CLASSROOMS. International Seminar on Generating Knowledge Through Research, 1, 421-430.

De Brito, J. (2015). The Effects of Listening Comprehension on English Language Learners Writing Performance while Taking Notesaking Notes.

Gilakjani, Abbas Pourhosein, \& Sabouri, N. B. (2016). Learners' Listening Comprehension Difficulties in English Language Learning: A Literature Review. English Language Teaching, 9(6), 123-133. https://doi.org/10.5539/elt.v9n6p123

Gilakjani, Abbas Pourhossein, \& Ahmadi, M. R. (2011). A Study of Factors Affecting EFL Learners' English Listening Comprehension and the Strategies for Improvement. Journal of Language Teaching and Research, 2(5), 977-988. https://doi.org/10.4304/jltr.2.5.977988

Graham, S. (2003). Learner strategies and advanced level listening comprehension. Language Learning Journal, 28(1), 64-69. https://doi.org/10.1080/09571730385200221 
Graham, S. (2017). Research into practice: listening strategies in an instructed classroom setting. Language Teaching, 50(1), 107-119. https://doi.org/10.1017/S0261444816000306

Hamouda, A. (2013). An Investigation of Listening Comprehension Problems Encountered by Saudi Students in the EL Listening Classroom. International Journal of Academic Research in Progressive Education and Development, 2(2), 113-155.

Hasan, M. M., \& Tan, B. H. (2012). ESL Learners' Perceptions and Attitudes towards the Use of Podcast in Developing Listening Skills. The English Teacher, 5(2), 160-173.

Hashim, H. U., Md Yunus, M., \& Hashim, H. (2018). Language Learning Strategies used by Adult Learners of Teaching English as a Second Language (TESL). TESOL International Journal, 13(4), 38-48.

Ismail, N. S. C., \& Aziz, A. A. (2020). The Teaching of Listening Strategies in ESL Classrooms. International Journal of Academic Research in Business and Social Sciences, 10(6), 183195.

Ivaarsson, E. (2013). Listening Strategies in the L2 Classroom. Malmö University.

Khan, K. S., Kunz, R., Kleijnen, J., \& Antes, G. (2003). Five steps to conducting a systematic review. Journal of the Royal Society of Medicine, 96(3), 118-121. https://doi.org/10.1258/jrsm.96.3.118

Lim, T. D. (2013). Analyzing Malaysian English Classrooms: Reading, Writing, Speaking and Listening Teaching Strategies. University of Washington.

Linang, E. R. (2005). Teachers Report On The Use Of Pre-Listening Activities In Activating Students' Prior Knowledge in a Malaysian ESL Classroom In Kuching. Universiti Malaysia Sarawak.

Liu, J. (2010). Language Learning Strategies and Its Training Model.

Mahmoud Ghoneim, N. M. (2013). The Listening Comprehension Strategies Used by College Students to Cope with the Aural Problems in EFL Classes: An Analytical Study. English Language Teaching, 6(2). https://doi.org/10.5539/elt.v6n2p100

Mejila, F. C., Calero, L. B., \& Salgado, K. A. (2014). The methodological strategies in the learningprocess of the English language. NATIONAL AUTONOMOUS UNIVERSITY OF NICARAGUA.

Nguyen, H., \& Abbot, M. L. (2016). Promoting Process-Oriented Listening Instruction in the ESL Classroom. TESL Canada Journal, 34(11), 72-86.

O'malley, J. M., Chamot, A. U., \& Küpper, L. (1989). Listening comprehension strategies in second language acquisition. Applied Linguistics, 10(4), 418-437. https://doi.org/10.1093/applin/10.4.418

Renandya, W. A., \& Farrell, T. S. C. (2011). "Teacher, the tape is too fast!" Extensive listening in ELT. ELT Journal, 65(1), 52-59. https://doi.org/10.1093/elt/ccq015

Renukadevi, D. (2014). The Role of Listening in Language Acquisition; the Challenges \& Strategies in Teaching Listening. International Journal of Education and Information Studies, 4(1), 59-63.

Santos, R. S. (2018). IMPROVING YOUNG LEARNERS' LISTENING SKILLS THROUGH STORYTELLING. Nova Lisbon University.

Sevik, M. (2012). Teaching Listening Skills to Young Learners through “Listen and Do" Songs. English Teaching Forum, 3, 10-17.

Vandergrift, L., \& Goh, C. (2009). Teaching and testing listening comprehension. In The Handbook of Language Teaching (pp. 395-411). Wiley-Blackwell.

Wong Min Ying, S., \& Abdul Aziz, A. (2019). Scaffolding Approach with Reading Strategies in 
Teaching Reading Comprehension to Rural Year 3 ESL Learners in Malaysia. International Journal of Current Innovations in Advanced Research Citation, 2(2), 6-26.

Woottipong, K. (2014). Effect of Using Video Materials in the Teaching of Listening Skills for University Students. International Journal of Linguistics, 6(4).

https://doi.org/10.5296/ijl.v6i4.5870

Yavuz, F., \& Celik, O. (2017). The importance of listening in communication. Global Journal of Psychology Research: New Trends and Issues, 7, 8. https://doi.org/10.18844/gjpr.v7i1.2431

Yıldırım, S., \& Yıldırım, Ö. (2016). THE IMPORTANCE OF LISTENING IN LANGUAGE LEARNING AND LISTENING COMPREHENSION PROBLEMS EXPERIENCED BY LANGUAGE LEARNERS: A LITERATURE REVIEW YABANCI DIL ÖĞRENIMINDE DINLEME BECERISININ ÖNEMI VE YABANCI DIL ÖĞRENENLERIN YAŞADIĞI DINLEME ANLAMA PROBLEMLERI: BIR ALANYAZIN DEĞERLENDIRMESI. Anadolu Üniversity.

Yukselci, S. (2003). TEACHERS' PRACTICES AND PERCEPTIONS REGARDING LISTENING STRATEGIES, AND PERCEPTIONS OF DIFFICULTIES LIKELY TO ARISE IN ENGLISH LISTENING COMPREHENSION LESSONS. BILKENT UNIVERSITY .

Zakaria, M. A., \& Abdul Aziz, A. (2019). The Impact of Digital Storytelling on ESL Narrative Writing Skill. Arab World English Journal, 5, 319-332.

https://doi.org/https://dx.doi.org/10.24093/awej/call5 